\title{
INNOVATION AS AN IMPORTANT PRODUCTION FACTOR AND A FACTOR IN INCREASING THE INVESTMENT ATTRACTIVENESS OF THE AGRICULTURAL SECTOR
}

\author{
Yuriy Kyrylov', Nadiia Stoliarchuk², Iryna Sadovska ${ }^{3}$, Andrii Bilochenko ${ }^{4}$, \\ Alina Matviienko ${ }^{5}$, Heorhii Khioni ${ }^{6}$ \\ ${ }^{1}$ Prof. Dr. Kherson State Agrarian University. Stritenska str. 23. 73006. Kherson. Ukraine. \\ Phone Number+380669564628. E-mail address kirilov_ye@ukr.net \\ ${ }^{2}$ PhD. National Scientific Centre, Institute of Agrarian Economics. Heroes of Defense str. 10. Kyiv. Ukraine. Phone \\ Number+380951007178. E-mail address stolyarchuk.iae@gmail.com \\ ${ }^{3}$ Prof. Dr. Lesya Ukrainka Eastern Europen National University. Voli Ave. 13. 43025. Lutsk. Ukraine. Phone Number \\ +380503398516. E-mail address irina_sadovska@ukr.net \\ ${ }^{4}$ PhD Candidate, National Scientific Centre, Institute of Agrarian Economics. Heroes of Defense str. 10. Kyiv. Ukraine. \\ Phone Number+380509039137.E-mail address abilochenko@yahoo.com \\ ${ }^{5}$ Postgraduate student, National Scientific Centre, Institute of Agrarian Economics, Heroes of Defense str. 10. Kyiv. \\ Ukraine. Phone Number+380976882429. E-mail address alina.pet.ma@gmail.com \\ ${ }^{6}$ Graduate student, National Scientific Centre „Institute of Agrarian Economics“, Kyiv, Ukraine. \\ E-mail: khioni.georgiy@gmail.com
}

Received 0804 2020; Accepted 18122020

\begin{abstract}
The paper considers the approaches to determination of the main investment attractiveness indicators by the approved methods. It is established that the investment attractiveness of financial statements in the modern world is increasingly dependent on innovative, i.e. intangible assets. It is determined that the main indicators characterizing the investment attractiveness are those of financial stability, business activity, assets, liquidity of assets and profitability. The purpose of the study is to identify the impact of intellectual property on the level of investment attractiveness of financial statements and to improve their balance reporting approaches. The methodology for identifying, evaluating and balancing intellectual property assets has been developed. Its effectiveness is established according to the simulated balance by way of example of the Plant Production Institute nd. a. V. Ya. Yuryev of National Academy of Agrarian Sciences of Ukraine financial statements.
\end{abstract}

Keywords: innovation, book value, asset, exclusive licenses, investment attractiveness, valuation.

JEL Codes: O32, E22, M21.

\section{Introduction}

In the modern world, trading licenses and patents exceeds that of other types of property. The core of the global and domestic innovation activity is science-intensive business entities. One of the most common ways of transferring intellectual property for use is license agreements. The main purpose of the license agreement is to ensure the practical use of a specific IPO. That is, the license also acts as an intellectual property entity and, accordingly, an accounting one. Innovative research institutions in Ukraine also receive funds from the use of intellectual property rights and knowledge-intensive products, but accounting for these processes is poor and the information in the financial statements is scarce and insufficient.

The purpose of the article is to identify the impact of intellectual property on the level of investment attractiveness of financial statements and to improve their balance presentation.

Copyright (C) 2020. Published by Vytautas Magnus University. This is an open access article distributed under the terms of the Creative Commons Attribution Non-Commercial 4.0 (CC BY-NC 4.0) license, which permits unrestricted use, distribution, and reproduction in any medium provided the original author and source are credited. The material cannot be used for commercial purposes. 
Object - innovative assets of the enterprise.

Subject - theoretical and methodological aspects of accounting for intellectual property objects.

Methodology for the investigation is based on the following components:

1) study of the nature of investment attractiveness, the main methods and indicators for its determining, in order to identify the factors that affect its performance;

2) analysis of the state of the enterprises innovation activity in Ukraine and the state of accounting of innovation in research institutions;

3) development of methodology for displaying and accounting of intellectual property objects on the balance of enterprises;

4) proving the effectiveness of the developed methodology by way of example of the simulated balance.

\section{Results}

On January 1, 2016, the 17 Goals set out in the Sustainable Development Agenda for 2030, which was adopted by the world leaders in September 2015 at the historic United Nations Summit, officially entered into force. The main ones are industrialization, innovation and infrastructure; effective institutions; partnership for sustainable development.

In particular, encouraging entrepreneurship and the development of firms is vital in addressing poverty and underdevelopment in developing economies (Korutaro, Biekpe, 2013, p. 41).

As United Nations Secretary-General Antonio Guterres said in UN report "The World Economic Status and Prospects", "there raise the issues related to the sustainability of global economic growth in the face of growing financial, social and environmental challenges" (Pressrelease, 2019). Therefore, innovation-based economic development is one of the important areas in the sustainable development context.

When making managerial decisions, innovation analysis can be used not only as a tool to assess the achieved level of activity and sustainability of the enterprise, but also to assess changes of this level under the influence of various technical and economic factors. At the same time, the evaluation and accounting of innovations in the process of reproduction of fixed capital is the most important means of identifying the internal reserves of improving the material and technical base of the organization, its data serve as an information source in making tactical and strategic decisions.

To date, scientists have proposed a number of methods for assessing and analyzing the enterprise investment attractiveness. They are usually classified into the following groups (Kolyada, Pulin, Nechaeva, 2018, p. 43):

1. Strategies, which source is financial reporting. Usually the financial condition of the enterprise is assessed;

2. Complex strategies of assessing investment attractiveness. In most cases, the integral indicator is used;

3. Strategies focused on the internal factors' classification of investment attractiveness potential;

4. European strategies of assessment and analysis of investment attractiveness, focused on rating.

As defined in the Strategies for Integral Evaluation of the Investment Attractiveness of Enterprises and Organizations, the investment attractiveness of an enterprise is the level of investor's financial, production, organizational and other requirements or interests satisfaction in a particular enterprise, which can be determined or estimated by the values of relevant indicators, including integrated valuation (Metodyka, 1998). 


\section{Table 1. Indicators of investment attractiveness (developed by the authors)}

\begin{tabular}{|l|l|}
\hline \multicolumn{1}{|c|}{ Indicator } & \multicolumn{1}{c|}{ Characteristics } \\
\hline $\begin{array}{l}\text { Property } \\
\text { valuation } \\
\text { indicators }\end{array}$ & $\begin{array}{l}\text { Allows determining how effectively the enterprise property is used. The indicators of this group } \\
\text { include: the amount of economic assets at the disposal of the enterprise, the rate of depreciation } \\
\text { of fixed assets, the rate of renewal, the rate of disposal etc. }\end{array}$ \\
\hline $\begin{array}{l}\text { Financial stability } \\
\text { (solvency) } \\
\text { indicators }\end{array}$ & $\begin{array}{l}\text { Characterize the enterprise ability to meet its short and long-term liabilities at the expense of its } \\
\text { own assets. The indicators of this group include: coefficients of absolute, urgent, intermediate } \\
\text { and total solvency. }\end{array}$ \\
\hline $\begin{array}{l}\text { Asset liquidity } \\
\text { valuation } \\
\text { indicators }\end{array}$ & $\begin{array}{l}\text { Characterize the borrower ability to ensure the timely fulfillment of their obligations, provide an } \\
\text { opportunity to predict the likelihood of the loan repayment under the agreement. These } \\
\text { indicators include: the ratio of the absolute, ultimate and current liquidity. }\end{array}$ \\
\hline $\begin{array}{l}\text { Profitability } \\
\text { indicators }\end{array}$ & $\begin{array}{l}\text { Characterize the enterprise profitability. The indicators of this group include: coefficients of } \\
\text { return on assets, equity, activity, produce. }\end{array}$ \\
\hline $\begin{array}{l}\text { Business activity } \\
\text { indicators }\end{array}$ & $\begin{array}{l}\text { Characterize the enterprise ability to use its resources effectively. Indicators of this group are: } \\
\text { sales of finished goods and services, income, amount of capital advanced. }\end{array}$ \\
\hline
\end{tabular}

The basis of almost every method of financial analysis is the analysis of the composition and structure of the enterprise assets and liabilities, the calculation of liquidity indicators, solvency, financial stability, profitability. However, each method proposes its own set of indicators and the procedure for their calculation. We consider approaches to determining the main indicators of investment attractiveness by the approved strategies. Based on the study of current approaches, it is established that investment attractiveness is considered as a characteristic of financial and economic and managerial activity of an enterprise, its development prospects and the possibility of attracting investment resources.

It is noted that the investment attractiveness of the enterprise is mainly characterized by the following factors: production funds, financial stability, financial independence, financial dependence, financial risk, and financial stability. To measure the performance of an enterprise, it is mainly based on the data obtained from the balance sheet and the statement of financial results.

At the same time, the investment attractiveness of the company is formed due to the competitiveness of its produce, customer orientation of the company, which is expressed in the most complete satisfaction of customer requests. Important for enhancing investment attractiveness is the level of innovation in the strategic development of the enterprise. It should be noted that the tasks of innovation implementation are leading in the whole system of factors that determine the investment attractiveness.

Investment support also plays an important role in the development of enterprise innovation. Having analyzed the capital investments by sources of financing, we can state that the main source during 2011-2018 are the own funds of enterprises and organizations. Among its own financial resources, the main ones are: the part of the profit that remains at the disposal of the organization; depreciation (Sergeyeva, Stolarchuk, Danylenko, Hong, 2020, p. 5317).

Earlier, undoubtedly, the value of an enterprise was considered the price of its tangible assets, since the assets were the property of the company, which is measured in monetary terms. With the emergence of intellectual capital, determining the real value of an enterprise or company is a pressing issue. "The value of Intel or Microsoft" said L. Edwison and M. Malone, "is determined not by the price of bricks and cement mortar, nor even by the value of their inventories, but by the categories of other intangible assets that called intellectual capital" (Edvinson Meloun M, 1999).

Analyzing international experience, we can conclude that foreign companies attach much more importance to innovation products. The impact of the Institute of Innovation on the economy abroad has led to the awareness and recognition of the new factors of production such as intellectual ones. This is reflected in the adopted regulations, the developed market for intellectual property, the methods of their protection, assessment strategies and, correspondingly, reflected in the reporting. According to the Economics of Industrial Research and Innovation, the share of intangible assets in the balance of the European Union (EU) countries is $23 \%$, the United States - 14\% and Japan - 
13.8\%. (Economics of Industrial Research and Innovation). In Ukraine the situation is different; the share of intangible assets in the balance of enterprises is $\approx 4 \%$, which is due to the slow development of new ones and the reform of basic institutions of socio-economic space.

Table 2. Implementation of innovations at Ukrainian industrial enterprises, units*

\begin{tabular}{|c|c|c|c|c|c|}
\hline Years & $\begin{array}{c}\text { Introduced } \\
\text { innovative } \\
\text { processes }\end{array}$ & $\begin{array}{c}\text { low-waste, resource- } \\
\text { saving innovative } \\
\text { processes }\end{array}$ & $\begin{array}{c}\text { Introduction of } \\
\text { innovative } \\
\text { products }\end{array}$ & $\begin{array}{c}\text { incl. new types of } \\
\text { machinery, equipment, } \\
\text { appliances, apparatus }\end{array}$ & Total \\
\hline 1 & 2 & 3 & 4 & 5 & 6 \\
\hline 2016 & 3489 & 748 & 4139 & 1305 & 7628 \\
\hline 2017 & 1831 & 611 & 2387 & 751 & 4218 \\
\hline 2018 & 2002 & 926 & 3843 & 920 & 5845 \\
\hline \multicolumn{7}{r}{ * Source: $h t t p: / / w w w . u k r s t a t . g o v . u a /$}
\end{tabular}

We have sampled information on the innovative activities of the research institutions that create varieties of wheat plants, and we found that, despite of the patenting of intellectual property rights and their commercial use, the value of intangible assets in the institutions is minimal, and in some of them is not defined at all.

Thus, for 2017-2018 the highest number of security documents for plant varieties was received by the Plant Production Institute nd. a. V. Ya. Yuryev of National Academy of Agrarian Sciences of Ukraine. According to the Table 3 we see that this institute made commercial use of the innovative produce, which allowed the institution to get in $2017-4557.8$ thousand UAH and in $2018-7857.0$ thousand UAH. However, the share of intellectual property in intangible assets was $0 \%$. The situation is different in the NAAS Institute of Agriculture, where the share of IP valuation on the balance is quite significant $(2017-40.8 \%, 2018-43.7 \%)$, but the number of patents is not very large ( $2017-17$ pieces and in $2018-4$ pieces).

Table 3. Information on innovative activities of the research institutions that create varieties of wheat plants*

\begin{tabular}{|l|c|c|c|c|c|c|c|c|}
\hline \multirow{2}{*}{$\begin{array}{l}\text { Name of research } \\
\text { institution }\end{array}$} & \multicolumn{2}{|c|}{$\begin{array}{c}\text { Created IPOR, } \\
\text { pieces }\end{array}$} & \multicolumn{2}{c|}{$\begin{array}{c}\text { Number of } \\
\text { concluded license } \\
\text { agreements, units }\end{array}$} & \multicolumn{2}{c|}{$\begin{array}{c}\text { Proceeds for licensing } \\
\text { agreements, ths UAH }\end{array}$} & \multicolumn{2}{c|}{$\begin{array}{c}\text { IPOR share in the } \\
\text { balance, \% }\end{array}$} \\
\cline { 2 - 10 } & $\mathbf{2 0 1 7} \mathbf{p .}$ & $\mathbf{2 0 1 8} \mathbf{~ p .}$ & $\mathbf{2 0 1 7} \mathbf{p .}$ & $\mathbf{2 0 1 8} \mathbf{~ p .}$ & $\mathbf{2 0 1 7} \mathbf{p .}$ & $\mathbf{2 0 1 8} \mathbf{~ p .}$ & $\mathbf{2 0 1 7} \mathbf{~ p .}$ & $\mathbf{2 0 1 8} \mathbf{~ p .}$ \\
\hline $\begin{array}{l}\text { NAAS Institute of } \\
\text { Agriculture }\end{array}$ & 17 & 4 & 114 & 116 & 1916,1 & 2105,1 & 40,8 & 43,7 \\
\hline $\begin{array}{l}\text { Institute of Agricultur } \\
\text { Polissia }\end{array}$ & 4 & 0 & 4 & 3 & 0 & 65,0 & - & - \\
\hline $\begin{array}{l}\text { Plant Production } \\
\text { Institute nd. a. V. Ya. } \\
\text { Yuryev NAAS }\end{array}$ & 43 & 28 & 338 & 305 & 4557,8 & 7857,0 & - & - \\
\hline $\begin{array}{l}\text { Myronivka Institute } \\
\text { of Wheat } \\
\text { nd.a.V. M. Remeslo) }\end{array}$ & 2 & 3 & 133 & 115 & 589,0 & 827,2 & 2,56 & 2,24 \\
\hline $\begin{array}{l}\text { Total } \\
\text { NAAS }\end{array}$ & $\mathbf{4 6 9}$ & $\mathbf{4 9 5}$ & $\mathbf{1 9 0 8}$ & $\mathbf{1 7 5 2}$ & $\mathbf{2 2 6 3 2 , 0}$ & $\mathbf{3 1 0 6 8 , 2}$ & $\mathbf{4 , 4 5}$ & $\mathbf{4 , 6 4}$ \\
\hline
\end{tabular}

* Source: Activity reports NAAS for 2017 - 2018.

This situation is due to the inactivity of the evaluation mechanisms and innovative produce accounting, and also the possibility of commercial use of a newly created product. Therefore, determining the value of intangible assets is one of the necessary steps to help solve the problem of property rights to use. 
According to foreign colleagues, "Results enhance the academic discussion on the impacts offormal standards and regulation on innovation. We show theoret-ically as well as empirically that both instruments have diverseeffects on innovation in different market conditions. In addition tothe contribution to literature, these results are particularly usefulfor policy makers to stimulate the discussion on how different reg-ulatory instruments should be used to shape the optimal regulatoryframework conditions in different market environments" (Blind, Petersen, Riillo, 2017, p. 250).

Intellectual property rights only are subject to the valuation and accounting as a part of intangible assets. In order to obtain them the scientific institution must submit an application to the relevant bodies, pass an examination and obtain a security document. Security documents confirming personal non-property right of authorship are the objects of statistical accounting, but they are not the objects of accounting and valuation, which makes it impossible to capitalize them.

Research institutes are the source of most of the intellectual property objects. According to the National Academy of Agrarian Sciences of Ukraine, the proceeds from the use of innovative products are made on the basis of economic agreements and license agreements. The peculiarity of intellectual property in the market is that it is not the produce that is the article of trade, but property rights to it. The commercialization of intellectual property objects in the innovation sphere is carried out by attracting intellectual property objects that are introduced into production as innovations, in order to ensure the development of basic industries, increase productivity and technological upgrading of production. More often, only the right of use is transferred. The license agreement is characterized by the features that are significant and characteristic of the lease. The conclusion of the license agreement under which exclusive rights are granted can be equated to a finance lease and transactions with other types of contracts - to an operating lease.

Table 3. Features of granted (received) licenses depending on the type of license

\begin{tabular}{|c|c|c|c|c|}
\hline License type & Licenser's rights & Licensee's rights & $\begin{array}{l}\text { Ability to } \\
\text { sublicense }\end{array}$ & Notes \\
\hline Exclusive (full) & $\begin{array}{l}\text { The use of this } \\
\text { object by the } \\
\text { licenser in the part } \\
\text { transferred to the } \\
\text { licensee is excluded }\end{array}$ & $\begin{array}{l}\text { The licensee is granted } \\
\text { the exclusive right to } \\
\text { use the intellectual } \\
\text { property in corpore }\end{array}$ & + & $\begin{array}{l}\text { Licensee's rights to use the IPO } \\
\text { are limited by the term and } \\
\text { territory of the agreement, as } \\
\text { well as by the method of use } \\
\text { specified therein }\end{array}$ \\
\hline $\begin{array}{l}\text { Non-exclusive } \\
\text { (simple) }\end{array}$ & $\begin{array}{l}\text { The exclusive rights } \\
\text { remain with the } \\
\text { licenser }\end{array}$ & Only use right is granted & - & $\begin{array}{l}\text { Provided when there is a } \\
\text { constant demand for products } \\
\text { manufactured using a patented } \\
\text { IP facility }\end{array}$ \\
\hline Single & $\begin{array}{l}\text { The exclusive rights } \\
\text { remain with the } \\
\text { licensor }\end{array}$ & Only use right is granted & - & $\begin{array}{l}\text { It is issued to only one licensor } \\
\text { and excludes the possibility of } \\
\text { issuing licenses to other persons }\end{array}$ \\
\hline Open & $\begin{array}{l}\text { The exclusive rights } \\
\text { remain with the } \\
\text { licenser }\end{array}$ & Only use right is granted & - & $\begin{array}{c}\text { When granting an open license, } \\
\text { the patent maintenance fee is } \\
\text { reduced by } 50 \%\end{array}$ \\
\hline Sublicense & $\begin{array}{l}\text { The use of this } \\
\text { object by the } \\
\text { licenser in the part } \\
\text { transferred to the } \\
\text { licensee is excluded }\end{array}$ & $\begin{array}{c}\text { Sublicense is granted in } \\
\text { a non-exclusive license } \\
\text { mode }\end{array}$ & - & $\begin{array}{l}\text { In case of sublicenses, the } \\
\text { licensee who has granted this } \\
\text { license shall be liable to the } \\
\text { licenser. }\end{array}$ \\
\hline
\end{tabular}

An important role is played by the fact that at the conclusion of the license agreement, the recipient is granted only the right of use, but the right of ownership remains with the owner, the creator of the intellectual property object. The main factor in the licensing relationship is the license agreement, its terms (Stolyarchuk, 2015). If you analyze the nature of the license agreement carefully, it can be stated that it is similar in many respects to the lease agreement. Accordingly, the 
accounting of licenses both by the licenser and the licensee will depend on the volume of rights transferred (received) and the type of license agreement to which the transfer is executed. Analyzing the features of each type of license, we can conclude that only those innovative products that combine the triad of ownership rights to an object, that is, transferred under the exclusive license, can be evaluated and balanced.

There are four criteria for recognizing an asset in the world to be reflected in financial statements:

- definition - object meets the definition of the financial reporting element;

- measurability - has characteristics that are measurable;

- relevancy - the information about the object can influence users' decisions;

- reliability - information is representatively reliable, neutral and can be verified (Financial Accounting Standards Board (1985) Elements of Financial Statements. SFAC 6).

These requirements are most fully met by the exclusive license. Therefore, the exclusive license obtained from the licensee must be valued and reflected in the intangible assets for the period of the license. And the one obtained from the licenser must be withdrawn for off-balance accounting. Intellectual property objects that are acquired for all other intangible assets cannot be displayed.

Taking into consideration the peculiarities of the exclusive license, we believe that property rights can be assessed using one of the three methods: market, revenue or cost. That means that the patent transferred under an exclusive license at the date of transfer is evaluated. The choice of the method depends on the type of IPO, the state of the intellectual property market at the time of the transaction, and the professional judgment of the value.

Summarizing the above, we can state that the main measures to increase the value of intangible assets on the balance of Ukrainian institutions and enterprises in order to increase the investment attractiveness of financial reporting indicators should be:

1. Awareness of the important role of intellectual property entities in the activities of business entities by accounting officers, managers and users of financial statements, with further reflection of their value in the balance;

2. Improving the nomenclature of research and development costs;

3. Capitalization of development costs;

4. Displaying the value of exclusive licenses on the balance as a part of intangible assets in the context of subaccounts;

5. Introduction of effective accounting and information support: creation of separate estimates, internal reports, which will allow recording in detail all expenses for an IPO creation.

In the context of solving this problem, Ukrainian scientists have developed a technique to increase the investment attractiveness of an agricultural enterprise in the part of assessment and registration of intellectual property, which includes 5 stages (Zhuk, Mel'nychuk, Bezdushna et al., 2013):

1. IPO Inventory. The purpose of the inventory is to reveal and identify intellectual property. In inventory, the key is to verify the relevant legal documents: patents, copyrights, trademark certificates, etc. As for the intellectual property received or transferred to use, it is to verify relevant license agreements.

2. Analysis of IPO law enforcement documents. Determining the IPO existence is to analyze the law enforcement documents for the entity, their validity, and the eligibility criteria for recognizing the entity as an intangible asset. Each law enforcement document confirming the enterprise's rights to the IPO is a unit of accounting for intangible assets and is subject to balance valuation and presentation.

3. Valuation of IPO identified during the inventory. IPOs are credited to the enterprise's balance at cost. The determination of the initial cost depends on how the asset came to the enterprise. For the purchased intellectual property, this is the cost of the acquisition. For the self- 
created IPOs, the initial cost consists of the relevant cost items. For the intellectual property acquired in exchange for a similar or dissimilar asset, free of charge, paid-in to the share capital obtained from a business combination or discovered in the course of an inventory, the cost of these enterprises is their fair value.

4. Balancing of IPO identified. IPOs, for which, according to the results of the inventory, the acts of introduction into the economic circulation of the object of intellectual property rights are drawn up and which value is determined, are included in the intangible assets of the enterprise.

5. Displaying IPO in the financial statements. In the prospectus an important place is given to presenting of the information on the availability of brands, trademarks and other intangible assets that increase the value of the enterprise. The market value of these assets, the description of their benefits, the profitability they provide, the available and possible directions of their involvement in the economic turnover, etc. are stated. The need for the preparation of the Information Prospectus is explained by theto date lack of a single source containing complete information about the company. The required information is partly contained in various reporting forms, which makes it impossible to use it effectively to assess the financial and property position of the enterprise.

We have analyzed the indicators of investment attractiveness before and after taking into balance account the cost of innovations, exclusive licenses and capital intangible investment, by way of example of the financial statements of the Plant Production Institute nd. a. V. Ya. Yuryev of NAAS.

Table 4. The proposals' effectiveness by way of example of the investment attractiveness analysis of the financial statements of the Plant Production Institute nd. a. V. Ya. Yuryev NAAS

\begin{tabular}{|c|c|c|c|c|}
\hline Indicator & $\begin{array}{c}\text { Value } \\
\text { real, 2018 year }\end{array}$ & $\begin{array}{c}\text { Value } \\
\text { modelled, 2018 year }\end{array}$ & Deviation & $\begin{array}{c}\text { Recommended value, } \\
\text { trends of changes }\end{array}$ \\
\hline Production funds coefficient & 0,461 & 0,766 & 0,305 & $0,5-0,65$ \\
\hline Financial stability coefficient & 12,00 & 37,35 & 25,35 & $>0,8$ \\
\hline $\begin{array}{c}\text { Financial independence } \\
\text { coefficient }\end{array}$ & 0,923 & 0,973 & 0,051 & $>0,5$ \\
\hline Financial dependence coefficient & 0,076 & 0,026 & $-0,051$ & $<0,5$ \\
\hline Financial risk coefficient & 0,083 & 0,026 & $-0,057$ & $<0,2$ \\
\hline Financial stability coefficient & 0,923 & 0,973 & 0,051 & $0,75-0,9$ \\
\hline
\end{tabular}

As a result of accounting and balance reflection of intangible assets, unfinished capital intangible investment and exclusive licenses, there was an improvement in the investment attractiveness of the financial statements of the Plant Production Institute nd. a. V. Ya. Yuryev of NAAS for 2015. Namely: the coefficient of production funds increased by 0.305 ; financial stability ratio - by 25.35 ; financial independence ratio - by 0.051 ; financial dependency ratio decreased by 0.051 ; the financial risk ratio decreased by 0.057 and the financial stability ratio increased by 0.051 , which is a positive phenomenon and allows to increase the level of investment attractiveness of the institute.

So, we can increase the investment attractiveness level and the industry competitiveness, which is in line with the main goals of the Agrarian Sector Development Strategy for the period up to 2025 and can reach the level of intangible balance assets corresponding to the level of the world's developed countries. 


\section{Conclusions}

Ukraine, like most countries in the world, has chosen an innovative path for its economic development. Intellectual assets are beginning to play an increasingly important role in the reporting structure of the enterprises. In the countries with developed innovation environment, such as EU countries, the USA, Japan, the share of innovative products in the balance is 23, 14 and $13.8 \%$ respectively. However, the share of innovative products in the balance of Ukrainian enterprises is only $4 \%$.

It is established that, despite patenting of intellectual property objects in 2017-2018, their development by production and commercial use during this period, the value of the intangible balance assets in the institutions is minimal, and in some is not defined at all. Thus, for the years 2017-2018, the largest number of patents was obtained by the Plant Production Institute nd. a. V. Ya. Yuryev of National Academy of Agrarian Sciences of Ukraine. However, there is generally no information on the value of the institution's intangible balance assets. There is the other state of affairs at the NAAS Institute of Agriculture, where the share of the intangible balance assets is quite significant, but the number of patents is not comparable. This situation certainly affects the investment attractiveness of the industry.

We have developed a series of actions to identify, evaluate and account intellectual property. In addition, the specifics of the license agreements were analyzed and found that the exclusive licenses meet the requirements of the asset and should be reflected in the financial statements.

The developed proposals have been successfully tested at the Plant Production Institute nd. a. V. Ya. Yuryev of National Academy of Agrarian Sciences of Ukraine. According to the simulated balance, which takes into account the value of intellectual property, exclusive licenses and capital intangible investment, investment attractiveness has improved significantly.

\section{References}

Blind K., Petersen S., Riillo C. (2017). The impact of standards and regulation on innovation in uncertain markets // Research Policy. № 46: 249-264. [27.03.2020].

Economics of Industrial Research and Innovation. Mode of access. - http://iri.jrc.ec.europa.eu/reports

Edvinson L., Meloun M. (1999). Intellektual'nyy kapital. Opredeleniye istinnoy stoimosti kompanii. Moscow: Akademiya. 465 p.

Financial Accounting Standards Board (1985) Elements of Financial Statements. SFAC $6 . \quad-$ https://ru.scribd.com/document/346529560/SFAC-NO-6 [27.03.2020].

Kolyada K.G., Pulin T.V., Nechaeva I.A. (2018). Metodyka otsinky investytsiynoyi pryvablyvosti ITkompaniyi za dopomohoyu pokaznykiv analizu aktsiy ta intehral'noho pokaznyka investytsiynoyi pryvablyvosti // Investytsiyi: praktyka ta dosvid. № 19: 41-45.

Korutaro B., Biekpe N. (2013). Effect of business regulation on investment in emerging market economies // Review of Development Finance. № 3: 41-50.

Metodyka intehral'noyi otsinky investytsiynoyi pryvablyvosti pidpryyemstv ta orhanizatsiy / Nakaz Ahentstva z pytan' zapobihannya bankrutstvu pidpryyemstiv ta orhanizatsiy vid 23.02.1998 № $22 . \quad-$ http://zakon1.rada.gov.ua/laws/show/z0214-98 [27.03.2020].

Press-reliz. Mirovoye ekonomicheskoye polozheniye perspektivy, 2019 god: Kratkoye rezyume [Press release. World Economic Outlook, 2019: A Brief Summary]. (n.d.). - https://www.un.org/development/desa/dpad/publication [27.03.2020].

Sergeyeva N., Stolarchuk N., Danylenko V., Hong Zh. (2020). Improvement of methodological approaches to accounting for sources of financing of capital investments with reference of Ukraine // International journal of scientific \& technology research. Volume 9, Issue 02:5316-5320. № 3: 55-61.

Stolyarchuk N.M. (2015). Oblik komertsiynoho vykorystannya innovatsiynoyi produktsiyi // Oblik $i$ finansy.

Zhuk V.M, Mel'nychuk B.V., Bezdushna Yu.S. et all. (2013). Oblikove zabezpechennia investytsiynoyi pryvablyvosti ta bezpeky pidpryyemstva ahrarnoyi haluzi: praktychne kerivnytstvo. - Kyiv: TOV "Vseukrayins'kyi instytut prava i otsinky". 88 p. 